\title{
O CONTROLE DE CONVENCIONALIDADE E A AUTOANÁLISE DO PODER JUDICIÁRIO BRASILEIRO
}

\section{THE CONVENTIONALITY CONTROL AND THE SELF-ASSESSMENT OF BRAZILIAN JUDICIARY}

\author{
Denisson Gonçalves Chaves* \\ Mônica Teresa Costa Sousa**
}

\begin{abstract}
RESUMO
O fenômeno do controle de convencionalidade das leis modificou o modo de compreender o Direito no mundo contemporâneo, unindo temas do direito internacional com metodologias do direito interno. Entretanto, muitos questionamentos com relação a este controle normativo ainda persistem. O objeto do presente artigo é discorrer sobre como o controle de convencionalidade tem transformado o entendimento do Poder Judiciário sobre a aplicação dos direitos humanos no Brasil. Utilizando-se de uma metodologia crítico-analítica, constata-se que o controle de convencionalidade, mais do que um exercício de controle normativo, é uma oportunidade para o Judiciário rever as concepções que tem sobre si mesmo.
\end{abstract}

\section{PALAVRAS-CHAVE}

Controle de convencionalidade. Sistema Interamericano de Proteção aos Direitos Humanos. Poder Judiciário.

\begin{abstract}
The phenomenon known as conventionality control of laws changed the way of understanding the Law in the contemporary world, putting together subjects of international law and domestic law methodologies. However, many questionings regarding this regulatory control still persist. The purpose of this paper is to discuss how the conventionality control has transformed the Judicial Branch's understanding about the implementation of human rights in Brazil. Using an analyticalcritical methodology, it is observed that the conventionality control, more than a normative control exercise, is an opportunity for the Judiciary to review its concepts about itself.
\end{abstract}

\section{KEYWORDS}

Conventionality control. Inter-American System for the Protection of Human Rights. Judicial Branch.

\footnotetext{
* Mestrando em Direito e Instituições do Sistema de Justiça pela Universidade Federal do Maranhão (PPGDIR/UFMA, São Luís, MA, Brasil). Bacharel em Direito pela Universidade Federal do Maranhão (UFMA/2014). Monitor da disciplina de Direito Internacional na Graduação em Direito na UFMA e na disciplina de Teoria do Direito Político no Programa de Pós-Graduação UFMA, ambas ministradas pelo professor PhD Cássius Guimarães Chai. Pesquisador Voluntário do Grupo de Ensino, Pesquisa e Extensão: Cultura, Direito e Sociedade. Assessor Jurídico no Ministério Público do Estado do Maranhão - 2014. E-mail: denissongoncalves@gmail.com

** Doutora em Direito pela Universidade Federal de Santa Catarina (2007). Professora Adjunta na Universidade Federal do Maranhão (São Luís, MA, Brasil). Bolsista de produtividade em pesquisa da Fundação de Amparo à Pesquisa do Maranhão (FAPEMA). Avaliadora do MEC/INEP. Coordenadora do Núcleo de Estudos em Direito e Desenvolvimento (NEDD/UFMA). Professora dos cursos de Mestrado em Direito e Instituições do Sistema de Justiça (PPGDir) e Mestrado Interdisciplinar em Cultura e Sociedade (PGCult).E-mail: mtcostasousa@uol.com.br
} 


\section{INTRODUÇÃO}

O Direito contemporâneo é marcado pelo dinamismo, complexidade e integração, características fomentadas pela proteção internacional dos direitos humanos e pelo protagonismo do Poder Judiciário, alterando de modo singular a relação entre ordem jurídica interna e internacional. Nesse quadrante, o controle de convencionalidade das leis surge como uma criação conjunta da atividade jurisprudencial e das normas e instituições reconhecidas nos diplomas internacionais. Todavia, sabe-se que a aplicação dos tratados e convenções internacionais de direitos humanos é temática recente no Brasil, restando muitas dúvidas quanto aos seus efeitos nos âmbitos jurídico e social.

Dessarte, buscar-se-á realizar uma análise crítica do fenômeno do controle de convencionalidade, partindo-se da esfera internacional até as particularidades do tema no ordenamento jurídico brasileiro, destacando as transformações que esse tipo específico de controle normativo produziu, principalmente no direito constitucional e no Poder Judiciário brasileiro.

Nesse seguimento, o primeiro capítulo preocupa-se com os aspectos gerais do controle de convencionalidade, analisando a origem, as delimitações conceituais e o contexto do surgimento do controle de convencionalidade. Ademais, será examinado por que o Poder Judiciário apresenta-se como uma instituição precípua para exercer esse controle de produção normativa.

O segundo capítulo trata da contextualização do controle de convencionalidade no Sistema Interamericano de Proteção aos Direitos Humanos, sob o regime da Convenção Americana de Direitos Humanos, que, devido a peculiaridades histórico-culturais dos países latino-americanos, desenvolvera-se de modo significativo, destacando-se para o papel desempenhado pela Comissão e Corte de Direitos Humanos, assim como a eficácia das sentenças da Corte Interamericana e a responsabilidade dos Estados diante da Convenção.

O terceiro e último capítulo constitui o próprio objetivo do presente artigo, que seja, discorrer sobre o controle de convencionalidade no Brasil e como a adoção desse procedimento tem afetado o Poder Judiciário pátrio, impulsionando-o a rever seu próprio papel na proteção e efetivação dos direitos humanos, postura denominada de “autoanálise”, em que o Judiciário é convocado a repensar a si mesmo.

\section{O CONTROLE DE CONVENCIONALIDADE: ASPECTOS GERAIS}

O controle de convencionalidade é um fenômeno historicamente recente; desse modo, não é de se estranhar que existam várias dúvidas sobre ele. No presente tópico pretende-se discorrer 
acerca das origens, de uma possível definição e do contexto sociojurídico de surgimento do controle normativo dos tratados e convenções internacionais de direitos humanos. Ademais, busca-se esclarecer o porquê de a análise de convencionalidade das leis incumbir ao Poder Judiciário e quais os efeitos de tal atribuição.

\subsection{ORIGEM, CONCEITOS E CONTEXTOS}

A experiência da humanidade diante das atrocidades ocorridas nas duas Grandes Guerras transformou de modo singular as relações sociais. O Direito, como uma ciência social, não poderia manter-se indiferente às mudanças estruturais e cognitivas que ocorreram e, deveras, coube a ele o papel de instrumento principal para proteção do homem, contra si mesmo e contra a razão de Estado $^{1}$. Nesse contexto de apoderamento do Direito como instrumento de proteção do homem, dois grandes ramos se destacaram: o direito internacional e os direitos humanos, de modo que, em meados do século XX, esse apoderamento culminou com o surgimento da corrente de pensamento jurídico denominada de Direito Internacional dos Direitos Humanos (TRINDADE, 2003, v. 3).

A proteção jurídica dos direitos humanos em escala global recebeu força do movimento constitucionalista e das vertiginosas publicações de textos internacionais de direitos humanos, destacando-se a Declaração Universal dos Direitos do Homem (1948), a Convenção Europeia de Direitos Humanos (1950) e a Convenção Americana de Direitos Humanos (1969). Todavia, a experiência mostrou, aos países comprometidos com a proteção dos direitos humanos, que se fazia necessária a criação de mecanismos e instituições que pudessem dar exequibilidade ao conteúdo positivado nas cartas internacionais, assim como à adoção de medidas de combate à mentalidade de supremacia da vontade estatal, vontade esta em detrimento da dignidade da pessoa humana.

Nesse rol de teorias e práticas protetivas, as cortes judiciais (nacionais e internacionais) assumiram o papel de protagonistas na defesa dos direitos humanos. Tanto na esfera do direito doméstico como na do direito internacional, a jurisdição demonstrou-se o modo mais (re)ativo na custódia de direitos e garantias fundamentais. Entretanto, a concepção de um direito interno autossuficiente e fechado em si mesmo ainda tem influência em muitas nações, de modo que tal postura hermética reflete na forma como o Poder Judiciário de cada Estado reconhece a atuação das

\footnotetext{
${ }^{1}$ A tradição de Razão de Estado afirma que a segurança do Estado é exigência de tal importância que os governos são obrigados a violar normas jurídicas, políticas, morais e econômicas que consideram imperativas. Nas palavras do teórico alemão Friedrich Meinecke (1957, p. 1), “a razão de Estado é o princípio fundamental de condução nacional, a primeira lei de movimento do Estado. Ela diz ao estadista o que deve fazer para preservar a saúde e a força do Estado". Assim, nota-se que a doutrina da Razão de Estado parte do pressuposto da presunção de incapacidade dos indivíduos em organizarem-se coletivamente, fazendo-se necessárias atitudes de governantes para reprimir interesses particulares que venham colocar em risco a segurança de Estados ou de seus dirigentes. Nesse contexto, não é difícil compreender a permissividade à guerra, sob a justificativa de “autopreservação”.
} 
cortes internacionais - se de maneira cooperativa ou subordinativa. Eleva-se então, nesse contexto de dificuldades, a necessidade de um diálogo interjurisdicional, que seja uma atuação conjunta do judiciário doméstico e dos organismos judiciais internacionais na defesa dos direitos humanos. Logo, como providência ao estabelecimento desse “diálogo interjurisdicional”, cria-se o controle de convencionalidade, fenômeno de compatibilização entre leis domésticas e tratados de direitos humanos, que constitui o objeto do presente trabalho.

O controle de convencionalidade é um conjunto de mecanismos que tem como objetivo a compatibilização das leis internas de um país com o conteúdo disposto nos tratados internacionais de direitos humanos por ele ratificado e em vigor no seu território. Trata-se de um conceito prévio, que necessita de aprofundamento, que será realizado no decorrer deste labor. Notam-se, aprioristicamente, dificuldades em entender como se dá essa análise de “compatibilização”, especialmente em dois pontos: a) determinar qual órgão tem competência para realizar o controle de convencionalidade e b) definir o modo de incorporação dos tratados internacionais de direitos humanos no ordenamento jurídico interno de cada Estado. Corrobora com este conceito o professor Valério de Oliveira Mazzuoli (2013, p. 5), um dos pioneiros ao tratar sobre o tema no Brasil, e que define o fenômeno do controle de convencionalidade nas seguintes palavras: “O Controle de Convencionalidade das leis é a compatibilização da produção normativa doméstica com os tratados de direitos humanos ratificados pelo governo e em vigor no país”.

A expressão “controle de convencionalidade” foi utilizada, pela primeira vez, pelo Conselho Constitucional Francês (na Decisão 74-54 DC, de 15 de janeiro de 1975, que tratava da análise de constitucionalidade de uma lei que versava sobre a interrupção voluntária da gestação, tendo em vista a possibilidade de violação do “direito à vida”, assegurado no art. $2^{\circ}$ da Convenção Europeia de Direitos do Homem, ratificada e reconhecida pelo Estado Francês). Ocorre que na França, por força do art. 61 de sua Constituição, as leis ordinárias, antes de sua aplicação, devem ser submetidas ao Conselho Constitucional, equivalente ao Supremo Tribunal Federal no Brasil (STF), para verificação de adequação com o texto constitucional - controle de constitucionalidade. Por sua vez, o art. 55 da Constituição francesa afirma que os tratados e acordos ratificados têm, a partir de sua publicação, hierarquia superior às leis ordinárias, restando, desse modo, ao Conselho Constitucional Francês, a análise de dois tipos de controle normativo: a adequação da lei com a Constituição e a adequação da lei com os tratados e acordos internacionais, de hierarquia superior. Nessa oportunidade, o Conselho francês reconheceu a existência de dois modos distintos de controle normativo: o controle de constitucionalidade e o controle de convencionalidade. Nas palavras da corte constitucional francesa: 
Considerando, em primeiro lugar, que nos termos do artigo 55 da Constituição: “Os tratados ou acordos regularmente ratificados ou aprovados têm, desde sua publicação, uma autoridade superior àquela das leis, sob condição, para cada acordo ou tratado, de serem aplicados pela outra parte” [...] Considerando, com efeito, que as decisões tomadas em aplicação do artigo 61 da Constituição revestem um caráter absoluto e definitivo, tal como resulta do artigo 62, que obsta a promulgação e a vigência de toda disposição declarada inconstitucional; que, ao contrário, a superioridade dos tratados sobre as leis, cujo princípio está estatuído no artigo 55 já citado, apresenta um caráter ao mesmo tempo relativo e contingente, tendo em vista, por um lado, que ela é limitada ao campo de aplicação do tratado e, por outro lado, que ela é subordinada a uma condição de reciprocidade cuja realização pode variar conforme o comportamento do ou dos Estados signatários do tratado e o momento em que deve ser apreciado o respeito dessa condição; [...] Considerando que assim o controle do respeito ao princípio enunciado no artigo 55 da Constituição não poderia ser exercido no contexto do exame previsto no artigo 61, em razão da diferença de natureza desses dois controles ${ }^{2}$.

A contribuição do tribunal francês é marcante, visto que, ao reconhecer “dois controles de natureza diferente”, deu nome a um fenômeno até então pouco discutido, de modo que contribuiu para seu amadurecimento posterior. É notório que a expressão “controle de convencionalidade” foi utilizada em analogia a "controle de constitucionalidade”, tendo em vista que esta última tem como ponto central a constituição, e aquela se refere aos acordos, tratados internacionais e convenções in casu, a Convenção Europeia de Direitos do Homem. Assim, o Conselho Constitucional da França asseverou que não se tratava de um caso que pudesse ser resolvido tão somente utilizando-se do controle de constitucionalidade, mas da identificação de um controle normativo com objeto, hierarquia e modo de aplicação distintos.

Da decisão que cunhou a expressão “controle de convencionalidade” podem-se perceber as características que levaram ao reconhecimento desse fenômeno jurídico. A primeira delas é a força do constitucionalismo, que, independentemente das críticas que se façam à supremacia ou não da Constituição sobre as normas de direito internacional ${ }^{3}$, é um movimento que notoriamente representou um apoderamento às cartas internacionais de direitos humanos, por meio de um processo de delegação de legitimidade, das constituições nacionais aos acordos e convenções internacionais. É o que se percebe na decisão da corte francesa, ao afirmar que o fundamento para o

\footnotetext{
2 “Considérant, en premier lieu, qu'aux termes de l'article 55 de la Constitution : "Les traités ou accords régulièrement ratifiés ou approuvés ont, dès leur publication, une autorité supérieure à celle des lois, sous réserve, pour chaque accord ou traité, de son application par l'autre partie.” ; [...] Considérant, en effet, que les décisions prises en application de l'article 61 de la Constitution revêtent un caractère absolu et définitif, ainsi qu'il résulte de l'article 62 qui fait obstacle à la promulgation et à la mise en application de toute disposition déclarée inconstitutionnelle ; qu'au contraire, la supériorité des traités sur les lois, dont le principe est posé à l'article 55 précité, présente un caractère à la fois relatif et contingent, tenant, d'une part, à ce qu'elle est limitée au champ d'application du traité et, d'autre part, à ce qu'elle est subordonnée à une condition de réciprocité dont la réalisation peut varier selon le comportement du ou des Etats signataires du traité et le moment où doit s'apprécier le respect de cette condition ; [...] Considérant qu'ainsi le contrôle du respect du principe énoncé à l'article 55 de la Constitution ne saurait s'exercer dans le cadre de l'examen prévu à l'article 61, en raison de la différence de nature de ces deux contrôles [...]" (Tradução nossa). (ECLI:FR:CC:1975:74.54.DC/ Journal officiel du 16 janvier 1975, page 671. Recueil, p. 19).

${ }^{3}$ Essa temática será trabalhada de modo mais detalhado no capítulo terceiro.
} 
reconhecimento de algum tratado ou acordo internacional no direito interno é, antes de tudo, um ato de obediência à Constituição, visto que a própria lei fundamental assegurou, a estes, local de destaque na pirâmide normativa. É devido ao constitucionalismo que se pode presenciar o movimento de internacionalização dos direitos humanos, que, de modo fático, foi um processo de constitucionalização dos direitos humanos, ou de humanização do direito constitucional.

A segunda característica perceptível é a insuficiência dos métodos tradicionais de resolução das antinomias no ordenamento jurídico. Sabe-se que, na perspectiva do direito interno, o saneamento de um conflito normativo dar-se-á por meio da aplicação de critérios objetivos, a saber: hierárquico, cronológico e de especialidade ${ }^{4}$. Todavia, diante da incorporação de um tratado ou acordo internacional no ordenamento jurídico interno, têm-se alguns problemas práticos. Dessarte, a mais importante dessas dificuldades é a de saber qual o status hierárquico que determinada norma internacional vai receber no momento de sua inserção no ordenamento jurídico interno, podendo ser considerada lei ordinária, norma de caráter supralegal ou até mesmo norma com status constitucional.

Optando-se pela primeira situação (normas internacionais com status de lei ordinária) temse a possibilidade de aplicação dos critérios objetivos de resolução de antinomias. Entretanto, tal circunstância é sem dúvida um retrocesso ao direito internacional dos direitos humanos, tendo em vista a fragilidade que as normas internacionais têm diante do parlamento nacional que, mediante uma lei posterior, poderia utilizar-se do critério cronológico para retirar-lhe validade. A segunda situação (normas internacionais com status de supralegalidade) é a mais recorrente nas disposições das atuais constituições ao redor do mundo. Percebe-se que a Constituição francesa optou por essa qualificação, o que significa um importante avanço, pois neutraliza a possibilidade de se subtrair a validade de uma norma internacional por meio dos critérios cronológico ou de especialidade. A outorga, às normas internacionais, de status hierárquico superior foi o primeiro passo para criação de um novo controle normativo diferenciado do controle de constitucionalidade. Por fim, a terceira situação (normas internacionais com status constitucional) é um fenômeno recente, que ganha fortes

\footnotetext{
${ }^{4}$ Os critérios objetivos de resolução de antinomias são trabalhados por diversos autores em obras introdutórias da ciência do direito e da teoria geral do direito. Destacam-se as obra de Norberto Bobbio, Teoria do Ordenamento Jurídico e Positivismo Jurídico. De acordo com o autor, em casos em que duas ou mais leis entrem em "aparente conflito”, resolver-se-á por meio do critério hierárquico, estabelecendo que lei superior derroga lei inferior, tomando-se como pressuposto a pirâmide normativa kelseniana. Quanto ao critério cronológico, considera-se o aspecto temporal, de maneira que lei posterior derroga lei anterior. Por fim, o critério de especialidade determina que leis específicas são preferíveis às leis gerais (BOBBIO, Norberto. Teoria do Ordenamento Jurídico. Trad. Maria Celeste. 6. ed. Brasília: Editora Universidade de Brasília, 1995; BOBBIO, Norberto. Positivismo Jurídico: lições sobre a filosofia do Direito. Trad. Marcio Publiesi, Edson Bini, Carlos E. Rodrigues. São Paulo: Ícone, 1995).
} 
adeptos, incluindo o Brasil ${ }^{5}$. Ademais, essa terceira possibilidade levanta muitos questionamentos e dúvidas que serão trabalhados ao longo do texto. Sabe-se, previamente, que as normas internacionais dotadas de status constitucional não estão submetidas aos critérios resolutivos de antinomias, mas a um controle normativo em nível constitucional.

Outrossim, além das características do controle de convencionalidade, a decisão do Conselho Constitucional francês chamou atenção para um paradoxo que constitui o próprio cerne deste trabalho: quem tem competência para exercer o controle de convencionalidade? Não foram poucas as críticas feitas à Corte Constitucional francesa devido ao posicionamento omissivo quando ao exercício do controle normativo de convencionalidade, expresso da seguinte maneira:

Considerando que, nessas condições, não compete ao Conselho constitucional, quando este é acionado em aplicação do art. 61 da Constituição, examinar a conformidade de uma lei às estipulações de um tratado ou de um acordo internacional; $[\ldots]^{6}$.

A inércia da corte francesa em assumir o compromisso com a defesa da Convenção Europeia de Direitos do Homem chama atenção para a discussão acerca da definição de qual organismo tem a competência para defesa e execução das cartas internacionais de direitos humanos. Parafraseando Carl Schmitt, em sua polêmica discussão com Hans Kelsen, trata-se, enfim, de saber: "quem é o guardião dos tratados e convenções de direitos humanos?"7. Nota-se que o Conselho Constitucional francês negou essa atribuição e não indicou a quem competia tal atividade. Assim, mesmo que a corte francesa tenha contribuído mais pelo erro do que pelo acerto, não se pode negar que a citada decisão colaborou para uma reflexão acerca do papel da jurisdição Estadual (nacional) e internacional no controle de convencionalidade.

\subsection{CONTROLE JURISDICIONAL DE CONVENCIONALIDADE}

O Conselho Constitucional da França repeliu, na Decisão 74-54 DC/1975, a atribuição de defesa dos tratados e acordos internacionais, tendo em consideração que a esta função já havia um

\footnotetext{
${ }^{5}$ Art. 5, §3 da Constituição da República Federativa do Brasil (BRASIL, 2015).

6 "Considérant que, dans ces conditions, il n'appartient pas au Conseil constitutionnel, lorsqu'il est saisi en application de l'article 61 de la Constitution, d'examiner la conformité d'une loi aux stipulations d'un traité ou d'un accord international” (Tradução: Rodrigo Arruda. ECLI:FR:CC:1975:74.54.DC/ Journal officiel du 16 janvier 1975, page 671. Recueil, p. 19).

${ }^{7}$ Hans Kelsen e Carl Schmitt travaram um diálogo acerca da competência para defesa da constituição no início do século XX. Carl Schmitt arguiu que a competência para defesa da constituição competia ao "Reich" - Chefe do Poder Executivo, na obra "O guardião da Constituição" (1929), alegando que, pelo fato de a constituição ser política, deveria ser salvaguardada por um poder político. Posteriormente, em 1931, Kelsen publicou o livro "Quem deve ser o guardião da Constituição?”, no qual defende que cabe a um tribunal constitucional a defesa da constituição de um Estado, pois a constituição não é apenas uma expressão política, mas norma jurídica (KELSEN, Hans. Jurisdição constitucional. São Paulo: Martins Fontes, 2007; SCHMITT, Carl. La defensa de la Constitución. Madrid: Tecnos, 1998; SCHMITT, Carl. O guardião da Constituição. Belo Horizonte: Del Rey, 2007).
} 
organismo competente: o Tribunal Europeu dos Direitos do Homem ${ }^{8}$, que tem o “fim de assegurar o respeito dos compromissos que resultam para Altas Partes contratantes” da respectiva Convenção. Logo, o real questionamento da corte francesa era se competia ou não à jurisdição interna exercer o controle de convencionalidade. Entende-se, e defende-se, que, diferentemente do egrégio tribunal francês, e em convergência com parte da atual doutrina do direito internacional público, compete tanto à jurisdição internacional (tribunais internacionais) quanto à jurisdição Estadual (nacional; juízes e tribunais domésticos) a proteção dos tratados e convenções de direitos humanos - ou seja, o exercício do controle de convencionalidade.

Um apontamento prévio deve ser feito antes de se discorrer sobre o controle de convencionalidade pelas jurisdições domésticas e internacional. Trata-se do fato de saber por que o poder Jurisdicional, e não o Legislativo e/ou Executivo, tem prevalência na defesa das normas internacionais de direitos humanos. Entende-se que um primeiro passo para responder essa questão está em destacar que se trata de "prevalência” ou mesmo "protagonismo", e não de "exclusividade". O direito internacional prega, em relação aos direitos humanos, uma ação sempre conjunta entre Poderes e instituições na proteção desses mesmos direitos, sendo impróprio falar-se de ações “isoladas” ou individualistas. Em segundo lugar, deve-se ressaltar que, em grande parte dos países, o Legislativo e o Executivo participam de modo conjunto no processo de incorporação, ao ordenamento jurídico pátrio, de tratados, convenções e acordos internacionais, a exemplo do que ocorre no Brasil.

A respeito desse último ponto, alguns doutrinadores defendem que o exercício de discricionariedade por parte do Executivo (negociação e ratificação dos diplomas internacionais) e do Legislativo (em alguns casos participa do processo de aprovação) se configuraria, mesmo que de modo indireto e restrito, em uma espécie de controle sobre os tratados e acordos de direito internacional. Não se pode negar que existe essa margem de discricionariedade, mesmo porque diz respeito ao exercício do poder de autodeterminação e de soberania do povo por meio de seus representantes. Todavia, não prospera tal posicionamento no sentido de que seja uma modalidade de “controle”, visto que são atribuições originárias do governo e do parlamento, respectivamente, negociar com instâncias internacionais e zelar pela coerência de produção normativa interna. Logo, não há que se falar em “controle”, mas sim em exercício das competências originárias (MAZZUOLI, 2013, p. 34).

Entende-se que o Judiciário é o Poder estatal destacado na defesa e garantia dos direitos humanos pelas mesmas razões aduzidas por Mauro Cappelletti em sua análise do direito judiciário,

\footnotetext{
${ }^{8}$ Ver artigos 19 e 31-35 da Convenção Europeia de Direitos do Homem.
} 
na obra “Juízes Legisladores?” (1999); quais sejam, as qualidades específicas do processo jurisdicional, que o autor italiano chama de "virtudes passivas" ou "limites processuais"9. O processo jurisdicional obrigatoriamente deve observar os princípios da imparcialidade (o julgador não pode ser parte nem litigar em causa própria), do contraditório (as partes têm oportunidade de defesa e participação na construção da decisão), da inércia (o julgador não pode dar início a um processo ex officio) e da inafastabilidade, do controle judicial, de ameaça ou ofensa a direito (CAPPELLETTI, 1999, p. 74).

Essas propriedades intrínsecas da jurisdição diferenciam-na dos processos de natureza política. O Legislativo e Executivo são naturalmente parcializados devido à fisiologia do argumento do princípio da maioria ${ }^{10}$. E é justamente o império do poder da maioria, expresso ou na soberania do parlamento ou no domínio absoluto do governo, que fortaleceu o constitucionalismo como uma resposta manifesta na limitação do poder político às diretrizes do Direito. Consequencialmente, as jurisdições constitucional e internacional destacam-se, por excelência, como meios de proteção de direitos e garantias fundamentais. Mauro Cappelletti comenta, nas seguintes palavras, esse agigantamento do Judiciário na defesa dos direitos fundamentais:

As proclamações (nacionais e supranacionais) de direitos fundamentais cessam de ser meras declamações filosóficas no momento em que sua atuação é confiada, em concreto, aos tribunais, ou a alguns tribunais, quer se trate de tribunais constitucionais nacionais, ou de organismos judiciários ou quase-judiciários transnacionais, assim como a Comissão e a Corte dos Direitos do Homem, instituída pelo Conselho da Europa, com sede em Estrasburgo (CAPPELLETTI, 1999, p. 66).

Verificam-se nas palavras de Cappelletti os traços do Direito no mundo contemporâneo, onde o Judiciário se agiganta diante do Legislativo e do Executivo, mas não somente isso - destacase também a percepção da existência de esferas jurisdicionais independentes e cooperativas entre si:

\footnotetext{
${ }^{9}$ Cappelletti afirma que as "virtudes passivas" ou "limites processuais" da atividade jurisdicional são "regras fundamentais da justiça natural" e, portanto, são características essenciais que diferenciam o processo jurisdicional do legislativo e do administrativo. $\mathrm{O}$ autor italiano defende que, no prisma substancial, não existe diferença entre atividade judicial e atividade legislativa: ambas criam o direto. Por sua vez, a peculiaridade distintiva encontra-se no caráter "formal e estrutural” das suas aplicações - por isso o termo "limites processuais", que são limites ao "poder político" na atividade jurisdicional, não presentes na atividade legiferante. Outrossim, o termo "virtudes passivas" é utilizado para demonstrar que essas características são virtudes do poder jurisdicional, pois impõem uma "passividade obrigatória" ao juiz em sua atuação, o que será manifesto no dever de agir de modo imparcial. Ver CAPPELLETTI, Mauro. Juízes Legisladores? Tradução de Carlos Alberto Alvaro de Oliveira. Porto Alegre: Sérgio Antonio Fabris, 1999. p 74-76.

${ }^{10} \mathrm{O}$ argumento do princípio da maioria defende que a validade da atuação estatal em um regime democrático está pautada nas decisões que encontrem guarida na legitimidade popular. Essa legitimidade é aferida de modo quantitativo, pelo maior número de pessoas que aprova ou reprova determinados posicionamentos. Ou seja, segundo tal princípio, não é admissível que decisões estatais sejam tomadas por uma pessoa (monarquia absolutista) ou por um restrito número de pessoas (oligarquias), pois teriam um défice de "participação popular". As eleições dos membros do Poder Legislativo e membros do Poder Judiciário são decisões essencialmente sob o crivo do princípio da maioria, e, por essa característica, os representantes do Legislativo e do Executivo têm um vínculo de defesa dos interesses com a porção popular que os elegeu. Essa defesa de interesses predeterminados configura o caráter parcializado da atuação legiferante e administrativa.
} 
as jurisdições nacionais e as transnacionais. Nesse quadro, conforme anteriormente mencionado, o controle de convencionalidade será exercido tanto pela jurisdição nacional como pela jurisdição transnacional.

O controle de convencionalidade exercido pelos tribunais das cortes internacionais (jurisdição transnacional) é produto das próprias convenções e tratados de direitos humanos que dispõem sobre a criação, estrutura e funcionamento de suas respectivas cortes julgadoras, tal como ocorre com o Tribunal Europeu de Direitos do Homem (1959) e a Corte Interamericana de Direitos Humanos (1979). Alguns doutrinadores, como Mazzuoli (2013, p. 37), postulam que o controle exercido pelas cortes internacionais não se caracteriza efetivamente como "controle de convencionalidade” pelo motivo do prejuízo do princípio do esgotamento das vias judiciais internas ${ }^{11}$. Contudo, entende-se que tal posicionamento é anêmico, pois acabaria por fragilizar as cortes internacionais e o vínculo de responsabilidade dos Estados signatários com os diplomas internacionais. A Corte Interamericana de Direitos Humanos já se manifestou no sentido de reconhecer a atividade dos tribunais internacionais como legítima aplicação do controle de convencionalidade:

De maneira semelhante à descrita no parágrafo anterior, existe um "controle de convencionalidade” depositado nos Tribunais Internacionais - ou supranacionais - criados por convenções de direitos humanos para interpretar e aplicar os tratados desta matéria e pronunciar-se sobre fatos supostamente violadores das obrigações estipuladas nestas convenções, que geram responsabilidade internacional para o Estado que ratificou a convenção ou aderiu a ela ${ }^{12}$.

Por outro lado, o controle de convencionalidade exercido pelos juízes e tribunais domésticos (jurisdição interna ou nacional) faz parte do objeto do presente trabalho. Assim,

\footnotetext{
${ }^{11} \mathrm{O}$ princípio do esgotamento das vias judiciais internas é um princípio do direito internacional que postula que as cortes internacionais somente atuarão depois de esgotadas as vias judiciais (e administrativas, se previstas) do direito interno. Nesse sentido, o já mencionado professor Valério de Oliveira Mazzuoli considera que o controle exercido pelas cortes internacionais seria uma espécie de controle de convencionalidade “complementar”, in verbis: "Assim, não é correto dizer que apenas o controle internacional de convencionalidade das leis (realizado pelas instâncias internacionais de direitos humanos) seria o verdadeiro controle de convencionalidade, uma vez que tal raciocínio guarda a insuperável incongruência de não reconhecer que é dos próprios tribunais internacionais (v.g., da Corte Interamericana) que decorre a exigência de os juízes e tribunais internos controlarem (em primeira mão, antes que qualquer manifestação internacional sobre o tema) a convencionalidade de suas normas domésticas. O controle de convencionalidade internacional é apenas coadjuvante ou complementar do controle oferecido pelo direito interno [...]”. Ver MARINONI, Luiz Guilherme; MAZZUOLI, Valério de Oliveira (Coord.). Controle de Convencionalidade. Um panorama latino-americano. Brasil, Argentina, Chile, México, Peru, Uruguai. 1. ed. Brasília: Gazeta Jurídica, 2013, p. 37.

12 “De manera semejante a la descrita en párrafo anterior, existe un 'control de convencioalidad' depositado en tribunales internacionales - o supranacionales - creados por convenciones de los derechos humanos interpretar y aplicar los tratados de esta materia y pronunciarse sobre hechos supuestamente violatorios de las obligaciones estipuladas en esos convenios, que generan responsabilidad internacional para el Estado que ratificó la convención o adhirió a ella” (CIDH, Casos dos trabalhadores demitidos do Congresso vs. Peru. Voto fundamentado do juiz Sergio García Ramirez, de 24.11.2006).
} 
consoante verificado na Decisão 74-54 DC/1975 do Conselho Constitucional da França, o entendimento de que compete ao Poder Judiciário interno exercer o controle de convencionalidade é recente. E, deveras, sofre várias resistências, em especial pela alegação de “afronta” ao princípio de soberania do Estado ${ }^{13}$, ainda que essa postura tenha sido adotada por vários países, como anteriormente dito, por especial contribuição do constitucionalismo, que impõe este tipo de controle ao Judiciário interno, por via de cumprimento de “obrigação constitucional”. Nesse contexto, os juízes, ao realizarem análise de validade das leis internas do ordenamento jurídico pátrio, devem ter como crivo de controle normativo, além da constituição, os tratados e convenções internacionais em vigor em seu país, aplicando, dessa maneira, o controle de convencionalidade (MAZZUOLI, 2013).

Portanto, sabe-se que o controle de convencionalidade pode (e deve) ser realizado pelas cortes transnacionais e pelos juízes e tribunais nacionais, de modo que não é admissível à jurisdição nacional (interna ou proveniente de outro Estado) abster-se de exercer essa tipologia de controle normativo, pelo fato de que tal exercício tem resguardo nas próprias normas constitucionais. Se o Poder Judiciário de um país se omite ou se nega a realizar o controle de convencionalidade, está, em última análise, abstendo-se de exercer, também, a justiça constitucional. Importa, por fim, destacar que, apesar de o surgimento da expressão controle de convencionalidade ter ocorrido na Europa, foi no continente americano que esse fenômeno ampliou-se e amadureceu, compondo assim um rol de mecanismos de defesa dos direitos e garantias do homem, denominado hodiernamente de Sistema Interamericano de Proteção aos Direitos Humanos (MAZZUOLI, 2013; TRINDADE, 2007, 2010).

\section{SISTEMA INTERAMERICANO DE PROTEÇÃO AOS DIREITOS HUMANOS}

As origens do controle de convencionalidade ocorreram na Europa; todavia, foi na América que este fenômeno se desenvolveu, tanto na modalidade do controle nacional como transnacional das convenções e tratados internacionais. Várias circunstâncias podem ser pontuadas como influentes para considerar o continente americano como um ambiente fértil para tal peculiaridade, mas destaca-se o fato de que os países latino-americanos têm regimes democráticos neófitos e ambivalentes, assim como suas cartas constitucionais, promulgadas recentemente e,

\footnotetext{
${ }^{13}$ O princípio de soberania postula que o povo tem o poder soberano de se autodeterminar por meio de suas leis e da escolha de seus representantes, os quais se manifestarão, em nome da nação, por meio da pessoa jurídica de direito público que é o Estado. Todavia, cabe realizar críticas quanto à visão moderna de "princípio de soberania”, que é expressa mais na "vontade soberana do Estado como pessoa abstrata" do que propriamente na "soberania do povo". O aparelhamento estatal - em especial, a administração - utiliza-se do argumento de soberania popular para proteger seus próprios interesses, que, em certas ocasiões, estão em contrariedade com os interesses do povo. É como se observa nos Estados totalitários e ditatoriais do século XX e meados do século XXI. Essa dissociação entre "soberania dos interesses do povo" e "soberania dos interesses do Estado (governo)” revela-se de modo mais nocivo nos países que adotam ideologias extremistas, com vulnerabilidade dos direitos humanos e constitucionalismo precário.
} 
portanto, sem um nível amadurecido de prática de efetivação de direitos. Ademais, os governos ditatoriais imprimiram nos povos das Américas uma percepção dos direitos humanos como uma “necessidade vital” para se evitar um sempre possível déjà-vu vu das ditaduras. Nesse contexto, vem sendo construído um Sistema Interamericano de Proteção aos Direitos Humanos, marcado não somente pela promulgação e ratificação de diplomas internacionais, mas precipuamente pela atuação jurisdicional em defesa dos direitos humanos.

\subsection{O REGIME DA CONVENÇÃO AMERICANA DE DIREITOS HUMANOS}

O Sistema Interamericano de Proteção aos Direitos Humanos é o conjunto de diplomas e instituições transnacionais que tem como objetivo a proteção e promoção dos direitos do homem no continente americano. O presente sistema apresenta dois regimes distintos: o regime da Carta da Organização dos Estados Americanos e o regime da Convenção Americana de Direitos Humanos, compostos por quatro diplomas normativos fundamentais: a Declaração Americana dos Direitos e Deveres do Homem (1948), a Carta da Organização dos Estados Americanos (1948), a Convenção Americana de Direitos Humanos (1969) e o Protocolo de San Salvador (1988), versando sobre direitos sociais e econômicos. No presente trabalho, far-se-ão sucintos apontamentos quanto à Declaração Americana, atendo-se de modo mais profundo ao regime da Convenção Americana.

A Declaração Americana dos Direitos e Deveres do Homem de 1948 é anterior à própria Declaração Universal dos Direitos do Homem, da Organização das Nações Unidas, também de 1948. Importa ressaltar que o respectivo diploma não possuía, à época de sua publicação, caráter vinculativo, adquirindo caráter deôntico somente em 1959, com a criação da Comissão Interamericana de Direitos Humanos. A Declaração Americana dos Direitos e Deveres do Homem representa um primeiro passo em prol da proteção dos direitos humanos na América, destacando-se por sua ousadia e pelo seu cabedal de direitos sociais e econômicos, mais amplo que o dos dispostos na Convenção (TRINDADE, 2010).

Hodiernamente, o diploma central do Sistema Interamericano de Proteção aos Direitos Humanos é a Convenção Americana de Direitos Humanos, aprovada em 1969 na cidade de San José da Costa Rica (por este motivo também é conhecida como Pacto San José da Costa Rica), na Conferência Especializada sobre Direitos Humanos da Organização dos Estados Americanos. O texto entrou em vigor, todavia, apenas em 1978. A citada Convenção teve como modelo, notoriamente, a Convenção Europeia de Direitos do Homem de 1950, conquanto aglutinou disposições da Declaração Americana de Direitos do Homem e do Pacto de Direitos Civis e Políticos (1966). Por ser resultado de uma condensação de normas protetivas de direitos humanos, a 
Convenção Americana é extensa, contendo 82 artigos, dois quais 23 tratam de direitos e garantias fundamentais, subdivididos categoricamente em direitos civis e políticos e direitos econômicos, sociais e culturais $^{14}$. Ademais, o diploma ainda diz respeito à estrutura e atuação de instituições próprias do Sistema Interamericano de Proteção aos Direitos Humanos (RAMOS, 2009).

O extenso, e qualificado, rol de direitos e garantias salvaguardados na Convenção Americana são reconhecidamente conquistas louváveis dos direitos humanos. Entretanto, duas características destacam-se como elementos significativos (e distintivos) do Sistema Interamericano à luz da Convenção. São eles: a) uma estrutura institucional de acompanhamento e controle do cumprimento da Convenção, por meio dos órgãos da Comissão Interamericana de Direitos Humanos e da Corte Interamericana de Direitos Humanos, e b) a previsão de responsabilidade dos Estados com o conteúdo da Convenção. Percebe-se que essas duas características se relacionam com a aplicação do controle de convencionalidade no continente americano e, consequencialmente, no Brasil.

\subsection{A COMISSÃO E A CORTE INTERAMERICANA DE DIREITOS HUMANOS}

A Comissão e a Corte Interamericanas de Direitos Humanos, conforme anteriormente mencionado, são os dois órgãos responsáveis por supervisionar e controlar o cumprimento das disposições da Convenção Americana de Direitos Humanos, tendo, respectivamente, a competência de promover ações e de sancionar violações contra os Estados-partes violadores de direitos humanos no continente americano. A Comissão Interamericana tem sede em Washington, nos Estados Unidos e a Corte Interamericana tem sede em San José, na Costa Rica.

A Comissão Interamericana de Direitos Humanos não é um órgão originário da Convenção, mas tem sua origem por meio de Resolução, no ano de 1959, da Assembleia Geral da Organização dos Estados Americanos. Na ocasião da sua criação, a Comissão estava adstrita à já mencionada Declaração dos Direitos e Deveres do Homem; porém, em virtude da publicação da Convenção, o órgão teve sua estrutura e funcionamento ampliados e fortalecidos (RAMOS, 2009). A Comissão tem como função "promover a observância e a defesa dos direitos humanos”"15, podendo formular recomendações, preparar estudos e relatórios, solicitar informações aos Estadosmembros, emitir pareceres consultivos e, mais importante, propor ação, contra Estados-membros,

\footnotetext{
${ }^{14}$ A Convenção Americana de Direitos Humanos codifica o direito à personalidade jurídica, à vida, ao tratamento humano, à liberdade pessoal, a liberdade de consciência, à religião, ao pensamento e à liberdade de expressão, à liberdade de associação, a um julgamento justo, à privacidade, ao nome, à nacionalidade, à participação no governo, à igual proteção legal e à proteção judicial. Ademais, a Convenção proíbe a escravidão e a aplicação da ex post facto law. ${ }^{15}$ Art. 41 da Convenção Americana de Direitos Humanos.
} 
na Corte Interamericana, por violação a direitos humanos.

Cabe, nesse momento, um apontamento. É importante destacar que a Comissão não tem legitimidade coativa para adotar medidas ou fazer cumprir postulados da Convenção, restringindo sua competência ao caráter "representativo" da vítima perante a Corte Interamericana. André de Carvalho Ramos afirma que esta competência, exercida pela Comissão, é semelhante à função desempenhada pelo Ministério Público no Brasil - qual seja, legitimidade processual e fiscalização da lei (RAMOS, 2009, p. 249).

Nesse sentido, qualquer pessoa ou grupo de pessoas ou entidade não-governamental pode peticionar perante a Comissão, desde que respeitados os requisitos de admissibilidade do art. $46^{16}$. Admitida a petição, a Comissão solicitará informações ao governo do Estado-membro denunciado, que apresentará resposta em prazo razoável, vindo posteriormente a Comissão a decidir se dará prosseguimento ao feito ou não ${ }^{17}$. Optando a Comissão pelo prosseguimento, serão utilizados métodos de resolução amistosa; não logrando êxito, o caso será remetido à Corte Interamericana. Note-se que a Comissão analisa tanto requisitos de admissibilidade como o mérito da causa. É, assim, “em termos práticos, o intérprete definitivo da Convenção Americana de Direitos Humanos” (RAMOS, 2009, p. 251).

Por sua vez, a Corte Interamericana de Direitos Humanos foi estabelecida no seio da Convenção, desempenhando duas funções distintas: consultiva e contenciosa. A função consultiva é aplicável a todos os Estados-membros da Organização dos Estados Americanos (OEA), e consiste na interpretação das normas da Organização e dos demais tratados de direitos humanos, assim como na análise de compatibilidade entre a produção normativa interna dos Estados-membros e os diplomas internacionais de direitos humanos. De outra parte, a função contenciosa é condicionada à aceitação de jurisdição obrigatória pelos Estados. No plano contencioso a Corte tem legitimidade para fazer cumprir o conteúdo decisório de suas sentenças.

Verifica-se que, tanto no exercício da função consultiva como no da função contenciosa, a Corte Interamericana realiza o controle de convencionalidade das leis. No primeiro caso, porque a Corte, por meio da consulta interpretativa, emite parecer acerca das diretrizes de aplicação dos

\footnotetext{
${ }^{16}$ Artigo 46 da Convenção Americana de Direitos Humanos: "Para que uma petição ou comunicação apresentada de acordo com os artigos 44 ou 45 seja admitida pela Comissão, será necessário: a) que hajam sido interpostos e esgotados os recursos da jurisdição interna, de acordo com os princípios de Direito Internacional geralmente reconhecidos; b) que seja apresentada dentro do prazo de seis meses, a partir da data em que o presumido prejudicado em seus direitos tenha sido notificado da decisão definitiva; c) que a matéria da petição ou comunicação não esteja pendente de outro processo de solução internacional; e d) que, no caso do artigo 44, a petição contenha o nome, a nacionalidade, a profissão, o domicílio e a assinatura da pessoa ou pessoas ou do representante legal da entidade que submeter a petição".

${ }^{17}$ Nessa etapa do processo, a Comissão poderá arquivar ou prosseguir com a petição. Em caso de arquivamento, não há previsão de recurso à vítima.
} 
tratados de proteção dos direitos humanos no plano jurídico interno, podendo consultar a “compatibilidade” entre as leis domésticas e a interpretação da Corte, consoante o art. 64, inciso 2: “A Corte, a pedido de um Estado-membro da Organização, poderá emitir pareceres sobre a compatibilidade entre qualquer de suas leis internas e os mencionados instrumentos internacionais”. A função contenciosa é, em si mesma, o exercício do controle de convencionalidade por meio do tribunal transnacional (ou regional) do continente americano, ou seja, a compatibilização entre as leis dos Estados-membros e as normas de proteção aos direitos humanos, por meio de um organismo jurisdicional - no caso, a Corte Interamericana ${ }^{18}$.

Todavia, cabe destacar uma crítica tecida à Convenção Americana de Direitos Humanos no que se refere à atuação da Corte. Conforme previsto no art. 61. 1, "Somente os Estados-partes e a Comissão têm direito de submeter um caso à decisão da Corte”. Isso significa que, ao contrário do que ocorre na Comissão, não se admite petição individual (proposição de ação pela vítima ou por seus representantes) perante a Corte Interamericana, diferentemente do que ocorre atualmente no regime da Convenção Europeia de Direitos do Homem - a qual, devido ao Protocolo ${ }^{0} 11$ (1998), passou a admitir essa possibilidade. No entendimento de Cançado Trindade, tal postura, adotada pela Convenção Americana, acaba por desvalorizar o direito subjetivo da pessoa humana de pleitear o respeito e a proteção de seus direitos diante de cortes internacionais, negando "a posição dos indivíduos como verdadeiros sujeitos do direito internacional dos direitos humanos” (TRINDADE, 2013, p. 26). A Convenção confunde, assim, procedimentalismo com formalismo, limitando o acesso jurisdicional ao principal interessado: a vítima ${ }^{19}$.

\subsection{AS SENTENÇAS DA CORTE INTERAMERICANA E A RESPONSABILIDADE DOS ESTADOS}

A característica que faz do Sistema Interamericano de Direitos Humanos algo distinto dos demais sistemas é a percepção que a Convenção faz das medidas de cumprimento e responsabilização dos Estados-membros perante o dever de observância dos tratados de direitos humanos no continente americano. Relembrando que, como a Convenção é o diploma fundamental

\footnotetext{
${ }^{18}$ A expressão controle de convencionalidade foi usada pela primeira vez pela Corte Interamericana de Direitos Humanos no julgamento do caso "Myrna Mack Chang v. Guatemala”, data de 25 de novembro de 2003.

${ }^{19} \mathrm{O}$ tema levantado por Cançado Trindade revela a importância da temática do acesso à Justiça, também ressaltado por Mauro Cappelletti e Bryant Garth no livro “Acesso à Justiça”, que embora trate do assunto de modo geral, leva a reflexões acerca do acesso as Cortes Internacionais de Direitos Humanos. Cabe então, expor o prévio conceito lançado pelo autor sobre o tema "A expressão "acesso a Justiça” é reconhecidamente de difícil definição, mas serve para determinar duas finalidades básicas do sistema jurídico - o sistema pelo qual as pessoas podem reivindicar seus direitos e/ou resolver seus litígios sob os auspícios do Estado que, primeiro deve ser realmente acessível a todos; segundo, ele deve produzir resultados que sejam individual e socialmente justos”. Ver CAPPELLETTI, Mauro; GARTH, Bryant. Acesso à Justiça. Tradução de Ellen Gracie Northfleet. Porto Alegre: Sergio Antonio Frabis, 1988, p. 3.
} 
do sistema americano de proteção aos direitos humanos, e como ela tem força normativa vinculante pela cláusula pacta sunt servanda, as disposições de “deveres” e “obrigações” aos Estadosmembros detêm caráter de obrigatoriedade, não podendo ser considerados meros standards retóricos. Nesse sentido a Convenção dispõe, logo em seus primeiros artigos:

Artigo $1^{\circ}$ Obrigação de respeitar os direitos

1. Os Estados-partes nesta Convenção comprometem-se a respeitar os direitos e liberdades nela reconhecidos e a garantir seu livre e pleno exercício a toda pessoa que esteja sujeita à sua jurisdição, sem discriminação alguma, por motivo de raça, cor, sexo, idioma, religião, opiniões políticas ou de qualquer outra natureza, origem nacional ou social, posição econômica, nascimento ou qualquer outra condição social.

[...]

Artigo $2^{\circ}$ Dever de adotar disposições de direito interno

Se o exercício dos direitos e liberdades mencionados no artigo $1^{\circ}$ ainda não estiver garantido por disposições legislativas ou de outra natureza, os Estados-partes comprometem-se a adotar, de acordo com as suas normas constitucionais e com as disposições desta Convenção, as medidas legislativas ou de outra natureza que forem necessárias para tornar efetivos tais direitos e liberdades ${ }^{20}$.

Percebe-se nos respectivos dispositivos da Convenção a presença de dois modos de atuação estatal perante os direitos e garantias reconhecidos no texto convencional: a "prestação ou deveres negativos” (Art. $1^{\circ}$ ) e a "prestação ou deveres positivos” (Art. $2^{\circ}$ ). A prestação ou deveres negativos são diretrizes e regras que proíbem o Estado de violar direitos ou garantias dispostas na Convenção ou no conjunto de normas de direitos humanos. Nesse caso, o termo "respeitar" acompanha o sentido de “abster-se de violar” direitos. A prestação ou deveres positivos são diretrizes ou regras que obrigam o Estado a adotar medidas necessárias e razoáveis para assegurar o pleno exercício dos direitos garantidos na Convenção. O termo “dever de adotar” significa prestação proativa e comprometida com fruição dos direitos humanos, de modo a torná-los exequíveis e efetivos.

O controle de convencionalidade enquadra-se de modo mais latente na forma de "prestação positiva”, uma vez que o exercício do controle de convencionalidade por parte dos juízes e tribunais nacionais é uma autêntica medida que visa efetivação dos direitos e liberdades da Convenção. Assim, quando a jurisdição interna aplica um tratado internacional de direitos humanos ou reconhece o precedente da Corte Interamericana, está comprometendo-se com o Sistema Interamericano de Proteção aos Direitos Humanos, que não se limita a atitudes legiferantes. Com efeito, pode-se afirmar que o art. $2^{\circ}$ da Convenção é um dos fundamentos mais sólidos para o controle de convencionalidade na esfera jurídica interna dos Estados-membros.

Os efeitos da “obrigação de respeitar direitos” e do “dever de adotar disposições de direito

\footnotetext{
${ }^{20}$ Ver artigos $1^{\circ}$ e $2^{\circ}$ da Convenção Americana de Direitos Humanos.
} 
interno” refletem no poder das decisões da Corte. Consoante art. 63. $1^{21}$, no caso de violação a direitos humanos, a Corte "determinará que se assegure ao prejudicado o gozo do seu direito ou liberdade violados”. Trata-se do princípio da restitutio in integrum como prioridade de prestação jurídica, fato que diferencia o sistema de proteção americano do sistema de proteção europeu. No sistema europeu existe a possibilidade da chamada "satisfação equitativa” de cunho pecuniário, no caso de óbices do direito interno para cumprimento da sentença internacional. Por sua vez, no sistema americano existe o dever do Estado de cumprir a sentença internacional em sua “integralidade”, assegurando à vítima o gozo do direito ou liberdade violada. A indenização é prevista no sistema americano com forma "indenizatória" à parte lesada, aplicada conforme procedimentos executórios do direito interno do Estado condenado. Nesse sentido, chama atenção André de Ramos Carvalho:

\begin{abstract}
Assim, exige-se o cumprimento no sistema interamericano das necessárias obrigações de fazer e não-fazer exigidas para que a vítima possa fazer valer o seu direito violado. Para tanto, não pode o Estado infrator alegar impedimento de Direito interno, como podem alegar seus pares europeus (vide a Convenção Europeia de Direitos Humanos e sua satisfação equitativa). Colabora para isso também o art. $2^{\circ}$ da Convenção Americana de Direitos Humanos, que firma o dever genérico dos Estados de introduzir toda e qualquer medida interna necessária para o cumprimento desta Convenção. Assim, as sentenças da Corte Interamericana de Direitos Humanos devem ser totalmente cumpridas, existindo a obrigação internacional derivada de cumprir de boa-fé tais decisões (RAMOS, 2009, p. 252).
\end{abstract}

Verifica-se que a obrigação do cumprimento integral do Estado às disposições das sentenças da Corte representa uma evolução do sistema interamericano em relação ao europeu, valendo constar que a Convenção Americana faz uso do entendimento disposto no art. 27 da Convenção de Viena (1969), ao afirmar que “uma parte não pode invocar as disposições de seu direito interno para justificar o inadimplemento de um tratado". A "satisfação equitativa" do sistema europeu representa vestígios da filosofia política da soberania ilimitada e dominadora do Estado em detrimento do reconhecimento da pessoa humana, mazela procedimental que o sistema americano buscou solucionar, ao adotar o instituto da "obrigatoriedade da satisfação integral”.

Dessarte, os Estados-membros da Convenção têm o compromisso de cumprir a decisão da Corte Interamericana, nos casos em que figurarem como parte (Art. 68,1), sendo a sentença definitiva e inapelável. Tanto a aplicação quanto a execução das sentenças da Corte Interamericana dependerão da normatividade interna do Estado condenado, devendo o mesmo adotar medidas

\footnotetext{
${ }^{21}$ Artigo 63. 1 da Convenção Americana de Direitos Humanos: "Quando decidir que houve violação de um direito ou liberdade protegidos nesta Convenção, a Corte determinará que se assegure ao prejudicado o gozo do seu direito ou liberdade violados. Determinará também, se isso for procedente, que sejam reparadas as consequências da medida ou situação que haja configurado a violação desses direitos, bem como o pagamento de indenização justa à parte lesada."
} 
cabíveis ao seu cumprimento, não podendo deixar de cumprir obrigação alegando ausência de lei. No caso de não cumprimento das decisões da Corte, esta indicará em seu relatório anual à Assembleia Geral da Organização dos Estados Americanos os casos em que determinado Estadoparte não deu cumprimento às suas sentenças.

\subsection{O BRASIL E O SISTEMA INTERAMERICANO DE PROTEÇÃO AOS DIREITOS HUMANOS}

O Brasil só passou a incorporar a Convenção Americana de Direitos Humanos em 11 de novembro de 1992, por meio do Decreto Presidencial $n^{\circ}$ 678. Todavia, somente em 10 de dezembro de 1998 a declaração de aceitação da competência obrigatória da Corte Interamericana de Direitos Humanos foi depositada na Secretaria-Geral da Organização dos Estados Americanos, e apenas a partir de 2002 o País passou a submeter-se à jurisdição obrigatória da Corte Interamericana, mediante o Decreto $\mathrm{n}^{\circ} 4.463$.

O Estado brasileiro já reconheceu, até a presente data (2015), diversos diplomas e instrumentos de Direito Internacional de Direitos Humanos, destacando-se: Declaração Americana dos Direitos e Deveres do Homem (1948); Convenção Americana sobre Direitos Humanos (1969); Convenção Interamericana para prevenir e punir a tortura (1985) e Convenção Interamericana para prevenir, punir e erradicar a violência contra a mulher (1994). Outrossim, em 2002 o Brasil reconheceu as competências dos comitês da Convenção para Eliminação de Todas as Formas de Torturas e Discriminação Contra a Mulher e da Convenção sobre Eliminação de Todas as Formas de Discriminação Racial.

Esse cenário de amplo número de direitos e garantias assegurados por meio dos tratados e convenções internacionais de direitos humanos, assim como pela própria Constituição de 1988, indubitavelmente provocou uma revolução copernicana na atuação dos juízes e tribunais no Brasil inclusive, e em especial, do Supremo Tribunal Federal (STF), que teve obrigatoriamente que rever seus posicionamentos enquanto cúpula máxima do Direito brasileiro, assim como sua participação fundamental na integração dos direitos humanos no ordenamento jurídico pátrio.

Destaca-se que após a edição da Emenda Constitucional n 45/2004 houve o que o ministro Gilmar Mendes, do STF, chamou de "necessidade da contínua e paulatina adaptação dos sentidos possíveis da Constituição"22. Todavia, conforme se defende neste trabalho, o controle nacional de convencionalidade não diz respeito tão somente a uma “adaptação interpretativa” das normas internacionais de direitos humanos, mas cumpre também a função de convocar os juízes e tribunais

\footnotetext{
${ }^{22}$ Ver Recurso Extraordinário 466.343-1, Relator Min. Cezar Peluso, Voto-vogal do Min. Gilmar Mendes.
} 
brasileiros a revisarem seus papéis na construção da sociedade e na proteção dos direitos humanos, seguindo a mesma trilha dos Estados modernos, no sentido de questionar "sua autorreferencialidade” como órgãos autossuficientes e fechados em si mesmo, para abrirem-se a diálogos (re)produtivos no viés dos direitos humanos, seja por meio da reciprocidade de legitimidade normativa, seja mediante o diálogo interjurisdicional.

\section{O CONTROLE DE CONVENCIONALIDADE NO BRASIL E A AUTOANÁLISE DO PODER JUDICIÁRIO}

A adesão tardia do Brasil ao Sistema Interamericano de Proteção aos Direitos Humanos é um sintoma da resistência do País no que diz respeito ao tema do controle de convencionalidade das leis. Tal relutância tem causas cognitivas e fisiológicas, próprias da realidade brasileira, destacandose a postura conservadorista e fechada dos juízes e tribunais brasileiros, que seguem a linha de pensamento do STF. Assim, destaca-se como óbice ao controle de convencionalidade a adoção da mentalidade de primazia do direito interno sobre o direito internacional, sustentada, até há pouco tempo, pelo Supremo Tribunal Federal e reproduzida pelos juízes e tribunais pátrios, somando-se à autointerpretação narcisista da magistratura brasileira.

Por outro lado, com a edição da Emenda Constitucional n ${ }^{\circ}$ 45/2004 e a vinculação obrigatória do Brasil à Corte Interamericana de Direitos Humanos, o Poder Judiciário brasileiro sofre, por força das instituições externas e da própria evolução do direito internacional dos direitos humanos, um impulso necessário a rever os conceitos e percepções sobre sua atuação no ordenamento jurídico nacional e internacional. Dessa maneira, o Poder Judiciário encontra-se diante da oportunidade de rever seu papel como instituição garantidora da justiça, não mais limitando-se a agir em “razão do/de Estado”, mas também para proteger os direitos e garantias de homens livres e iguais.

\subsection{OS TRATADOS INTERNACIONAIS NO BRASIL SOB A ÓTICA DAS TEORIAS MONISTA E DUALISTA}

Sabe-se que no Brasil existem dois regimes jurídicos aplicados aos tratados internacionais: a) regime dos tratados internacionais de direitos humanos e $b$ ) regime dos tratados internacionais de direito comum (RUSSOWSKY, 2012). A distinção entre os dois regimes encontra-se no conteúdo e na hierarquia com que os respectivos diplomas internacionais são inseridos no ordenamento jurídico interno. Atualmente, os tratados de direitos humanos são hierarquicamente superiores aos tratados comuns, porém nem sempre foi assim, tendo em vista que o posicionamento vigente acerca dos 
tratados de direitos humanos resulta de uma criação jurisprudencial ${ }^{23}$. Assim, os questionamentos acerca da hierarquia dos tratados internacionais têm fundamento em uma antiga discussão acerca da relação entre o direito interno (nacional ou estadual) e o direito internacional, formulada em duas linhas teoréticas: monismo e dualismo.

A teoria monista tem como expoente o jurista austríaco Hans Kelsen, e concebe as normas internacionais e nacionais como um todo, uma unidade cognoscitiva do Direito, na qual existe uma unitariedade entre Estados singulares e ordem jurídica internacional. Segundo a corrente monista, o juiz deve aplicar o direito interno e o direito internacional, pelo fato de compreendê-las como esferas jurídicas integradas. Por sua vez, a concepção dualista (ou pluralista) considera o direito internacional como independente do Direito nacional, isolados um em face do outro, tendo em vista o fato de serem baseados em normas fundamentais distintas. Nesse sentido, as regras de direito internacional somente adentram na esfera do direito interno por meio da permissão do ordenamento jurídico pátrio.

Kelsen rejeita a concepção dualista, afirmando que a mesma é “insustentável”, tendo em vista que as duas ordens jurídicas (do Estado e internacional) podem ser simultaneamente válidas e não contraditórias entre si. Nesse sentido, o autor declara que "não há qualquer conflito entre Direito Estadual e Direito Internacional” (KELSEN, 1998, p. 234), visto que existe uma “inevitabilidade de uma construção monista”. Exsurge assim, no interior da construção monista, duas possibilidades interpretativas: o direito internacional como ordem jurídica incorporada pelo direito Estadual, isto é, a ordem jurídica internacional ancorada na ordem jurídica Estadual, desta recebendo validade e reconhecimento. A esta interpretação dá-se o nome de "primado da ordem jurídica de cada Estado”. Por outro lado, a doutrina que coloca a ordem jurídica internacional como superior às e delegatária das ordens jurídicas Estaduais (estas, tidas como supraordenadas e parciais) denomina-se de “primado da ordem jurídica internacional” (KELSEN, 1998, p. 234-242).

A Corte Interamericana de Direitos Humanos e parte da doutrina brasileira são partidárias da teoria monista com primazia do direito internacional ${ }^{24}$. Assim, tanto os diplomas internacionais sobre direitos humanos como as decisões da Corte Interamericana constituem fontes lato sensu do Direito, devendo ser, portanto, aplicadas pelos juízes e tribunais brasileiros. É o chamado “bloco de convencionalidade”25. Ademais, cumpre destacar que estão em vigor no Brasil tanto a Convenção

\footnotetext{
${ }^{23}$ Comparar: <ADI-MC 1.480. Relator: Min. Celso de Mello. Brasília, 04/09/1997. Publicado em 18/05/2001> com $<$ Recurso Extraordinário 466.343-1, relator Min. Cezar Peluso, voto-vogal do Min. Gilmar Mendes>.

${ }^{24}$ Nesse sentido posicionam-se Valério de Oliveira Mazzuoli, André de Carvalho Ramos, Celso de Albuquerque Mello e Flávia Piovesan. Ver RUSSOWSKY, Iris Saraiva. O Controle de Convencionalidade das leis: uma análise na esfera internacional e interna. Revista do CAAP. Belo Horizonte. N ${ }^{\circ}$ 2. v. XVIII. P. 61-96, 2012.

${ }^{25}$ Conjunto de diplomas e decisões nacionais e internacionais que versam sobre direitos humanos aplicáveis no controle
} 
de Havana (1928) como a Convenção de Viena (1969), que, respectivamente, em seus artigos 11 e 27, estabelecem a supremacia do direito internacional sobre o direito interno, impondo, pelo menos na abstratividade, a aplicação da teoria monista ao ordenamento jurídico pátrio.

\subsection{O SUPREMO TRIBUNAL FEDERAL E A TEORIA DUALISTA: O MITO DA AUTOSSUFICIÊNCIA}

A despeito do posicionamento doutrinário e da Corte Interamericana, entende-se que o Supremo Tribunal Federal brasileiro adota a teoria dualista, ou seja, o entendimento de que existem duas esferas jurídicas ambivalentes e independentes que não se comunicam. A interlocução entre a esfera de direito internacional e a esfera de direito nacional só é possível se a constituição Estadual recepcionar os tratados e convenções internacionais. A postura dualista do STF é percebida quando considerada a necessidade de promulgação de decreto presidencial ou quórum legislativo para que o tratado internacional passe a ter validade no território brasileiro.

Destaca-se no presente trabalho que a postura dualista não é apenas uma questão de partidarismo teorético, mas a expressão de um Poder Judiciário que se considera "isolado” do ordenamento jurídico internacional. O entendimento dualista do STF é marca de um conservadorismo e formalismo do Poder Judiciário brasileiro, que demonstra forte resistência em dialogar com outras fontes jurídicas. Kelsen, forte opositor da corrente dualista, afirmava que tal raciocínio decorre da mentalidade “nacionalista” fundamentada na adoração ao conceito nebuloso, porém, trivializado, de “soberania” (KELSEN, 1998, p. 242). Quando a Suprema Corte brasileira infere que os tratados de direitos humanos são condicionados à "permissão do Estado" para entrar em vigor no País, entende-se que os direitos humanos estão submissos à vontade estatal. Nesse sentido, já se manifestou o STF pela paridade entre tratados internacionais e leis ordinárias:

\footnotetext{
Os tratados ou convenções internacionais, uma vez regularmente incorporados ao direito interno, situam-se, no sistema jurídico brasileiro, nos mesmos planos de validade, de eficácia e de autoridade em que se posicionam as leis ordinárias, havendo, em consequência, entre estas e os atos de direito internacional público, mera relação de paridade normativa. ${ }^{26}$
}

Entende-se que a adoção da corrente dualista é produto de uma ilusão: “o mito da autossuficiência” do Estado - leia-se, do Poder Judiciário -, como independente e isolado da ordem jurídica internacional. Tal postura narcisística do direito interno demonstra-se ruinosa à proteção de

de convencionalidade. Ver RAMOS, André de Carvalho. Supremo Tribunal Federal brasileiro e o Controle de Convencionalidade: levando a sério os tratados de direitos humanos. Revista da Faculdade de Direito da Universidade de São Paulo. V 104. p. 241-286. jan/dez.2009.

${ }^{26}$ ADI-MC 1.480. Relator: Min. Celso de Mello. [...] Controle de constitucionalidade de tratados internacionais no sistema jurídico brasileiro. Brasília, 04/09/1997. Publicado em 18/05/2001. 
direitos e liberdades fundamentais, uma vez que resta comprovada a vulnerabilidade das normas sobre direitos humanos quando equiparadas às leis ordinárias, tendo em vista a suscetibilidade de revogação por lei posterior ou especial.

Entretanto, com a vigência da Emenda Constitucional n 45/2004, a corrente dualista, assim como o mito da autossuficiência do direito interno, perderam espaço na doutrina e na jurisprudência brasileira. Primeiro devido à previsão da "equivalência” dos tratados de direitos humanos às emendas constitucionais; ou seja, há a possibilidade de elevação de normas internacionais de direitos humanos ao nível (formal e materialmente) constitucional. E, em segundo lugar, pela decisão do Supremo Tribunal Federal quanto ao RE 466.343, a qual aponta para a teoria monista, com primazia do direito internacional dos direitos humanos.

\subsection{AUTOANÁLISE DO PODER JUDICIÁRIO BRASILEIRO COM RELAÇÃO AOS DIREITOS HUMANOS}

A EC $n^{0} 45 / 2004$ representa um marco no que se refere ao controle de convencionalidade no Brasil e à atuação do Poder Judiciário na proteção dos direitos humanos. A citada emenda adicionou o $\S 3^{\circ}$ ao art. $5^{\circ}$ da Constituição brasileira, dispondo que "os tratados e convenções internacionais sobre direitos humanos que forem aprovados, em cada Casa do Congresso Nacional, em dois turnos, por três quintos dos votos dos respectivos membros, serão equivalentes às emendas constitucionais” (BRASIL, 1988).

A inserção desse dispositivo no texto constitucional resultou nas seguintes alterações: 1) passa a existir uma dupla compatibilidade vertical material ${ }^{27}$ para produção normativa no direito doméstico: a compatibilidade das leis com a Constituição e a compatibilidade das leis com as convenções e tratados internacionais de direitos humanos (MAZZUOLI, 2013, p. 4-7); 2) passa a haver dois regimes de diplomas internacionais de direitos humanos na ordem jurídica brasileira. $\mathrm{O}$ regime dos tratados de direitos humanos adotados pela Constituição, mas que não passaram pelo quórum legislativo, consoante o art. $5^{\circ}, \S 2^{\circ}$, possuindo status de norma constitucional (âmbito material), e o regime dos tratados de direitos humanos equivalentes às emendas constitucionais, que passaram pelo quórum legislativo, de acordo com o $\S 3^{\circ}$ do art. $5^{\circ}$, sendo considerados, formal e materialmente, constitucionais; 3) passa a ser possível a utilização de ações constitucionais (ADI, ADC, ADPF, ADO) para exercer o controle de convencionalidade no País.

Mas, além das modificações supramencionadas, entende-se que a mudança substancial na aplicação do controle de convencionalidade no Brasil seja o giro hermenêutico do Poder Judiciário

\footnotetext{
${ }^{27}$ MARINONI, Luiz Guilherme; MAZZUOLI, Valério de Oliveira, 2013, op. cit.
} 
brasileiro, com a retificação do entendimento do Supremo Tribunal Federal em relação ao conflito entre direito interno e direito internacional, possibilitando ao Judiciário uma visão holística e integracionista do Direito.

A emblemática decisão do STF no RE 466.343, em 2008, deveras foi resultado da influência da EC $n^{0}$ 45/2004. No citado julgamento, a Corte brasileira modificou seu posicionamento acerca da hierarquia dos tratados internacionais de direitos humanos não acobertados pelo quórum legislativo do $\S 3^{\circ}$ do art. $5^{\circ}$ da CRFB/1988, os quais passaram do status de lei ordinária para o de “norma supralegal”. O caso em questão tratava da análise da prisão civil por dívida - a Constituição admitia a prisão por dívida do depositário infiel e do devedor de alimentos. Contudo, o Pacto de San José da Costa Rica ${ }^{28}$ não previa a prisão por dívida do depositário infiel, havendo uma incompatibilidade entre os textos normativos. Nessa ocasião, o Supremo Tribunal Federal manifestou-se no sentido de que os tratados internacionais de direitos humanos possuem status supralegal. Como a prisão civil do depositário infiel depende de lei para sua aplicabilidade (eficácia limitada), qualquer norma regulamentadora nesse sentido seria considerada inconvencional, e, portanto, inválida. Ademais, cabe destacar que outros ministros, seguindo o entendimento do Min. Celso de Mello, posicionaram-se pelo status constitucional dos tratados de direitos humanos recepcionados pelo Brasil, sem necessidade do quórum legislativo.

Assim, a mudança de entendimento da Suprema Corte brasileira representa uma quebra do paradigma do Judiciário como um sistema fechado, em que as fontes jurídicas domésticas e internacionais anulam-se em caso de conflito. A resistência dos juízes e tribunais nacionais em exercer o controle de convencionalidade e aplicar os tratados e convenções internacionais de direitos humanos não é um problema meramente dogmático, mas um óbice comportamental e cultural da magistratura brasileira, que reluta às transformações dinâmicas da sociedade globalizada, apegando-se ao conservadorismo hermético que, demasiadas vezes, inviabiliza a efetivação de direitos e liberdades.

\section{CONSIDERAÇÕES FINAIS}

O controle de convencionalidade apresenta-se como um mecanismo eficiente à proteção e efetivação dos direitos humanos, tanto no Brasil como nos sistemas regionais e transnacionais de proteção aos direitos do homem. As transformações geradas pelo controle de convencionalidade vão

\footnotetext{
${ }^{28}$ Cabe destacar que a ratificação do Pacto de San José da Costa Rica foi anterior à EC n 45/2004 - a saber, 1992 -, então não possuindo, o diploma, status constitucional. Desse modo, o caso em questão tratava-se de definir os limites hierárquicos dos tratados e convenções não aprovados pelo quórum legislativo.
} 
além de modificações estruturais - são mudanças de postura e de interpretação do Direito em sua totalidade. Conforme exposto, não é possível admitir que os juízes e tribunais brasileiros restrinjamse às fontes internas do Direito. Isso porque, para que os direitos e a liberdade dos homens possam ser respeitados, é preciso ir além das limitações políticas do Estado. É forçoso compreender o Direito além do Estado, o Direito sob a perspectiva do ser humano.

O objetivo do presente trabalho é chamar atenção para a oportunidade contextual em que se encontra o Judiciário brasileiro, ante o notável crescimento do direito internacional dos direitos humanos; este representa não um movimento doutrinário ou ideológico, mas um novo olhar sobre as relações entre os homens e sobre o papel do Estado nesses vínculos. Na contemporaneidade, o Poder Judiciário é convocado a dizer o direito nas dinâmicas relações sociais. Uma postura de menoscabo com as novas fontes jurídicas (internacionais) é um posicionamento não condizente com a finalidade proposta pelo Sistema Interamericano de Proteção aos Direitos Humanos; por tal motivo, o controle de convencionalidade exsurge como um "dever/poder" de aplicar os direitos humanos no âmbito jurídico interno de cada Estado.

Conforme demonstrado, o Judiciário brasileiro é marcado pelo autocentrismo, no qual as decisões judiciais reconhecem as fontes jurídicas internas como autossuficientes, sob a égide de uma concepção primitiva de soberania, dando um falso aspecto de esgotamento dos instrumentos normativos de proteção aos direitos humanos. O mito da autossuficiência traduz-se na cegueira de parcela do Judiciário em perceber alternativas eficazes de combate à violação de direitos e liberdades. Defende-se, no presente labor, que o fenômeno do controle de convencionalidade é um despertar sistêmico; um espaço de (re)construção objetiva e cultural do modo de reconhecer os direitos humanos como um conjunto de elementos integralizados.

Desse modo, o Poder Judiciário brasileiro tem essa oportunidade de refletir sobre sua função e suas competências, podendo decidir pela integração ou pelo isolamento do Sistema Interamericano de Proteção aos Direitos Humanos. Percebe-se que, nos últimos julgamentos sobre a temática, o Supremo Tribunal Federal posicionou-se pela ótica “integracionista”, decidindo pela prevalência dos tratados internacionais de direitos humanos sobre as leis ordinárias na esfera jurídica interna. Deveras, o STF, ao adotar o primado do direito internacional de direitos humanos, manifestou-se pela prevalência do homem sobre as razões exclusivistas do Estado, tendo necessariamente que repensar a si mesmo como órgão estatal. Assim, conclui-se que o controle de convencionalidade é um chamamento ao Poder Judiciário, para a defesa do ser humano além das fronteiras territoriais, ideológicas e políticas. 


\section{REFERÊNCIAS}

BRASIL. República Federativa do. Constituição da República Federativa do Brasil. Brasília, DF: Senado Federal, Centro Gráfico, 1988.

. Emenda Constitucional $n^{\circ} 45$, de 30 de dezembro de 2004. Altera dispositivos dos arts. $5^{\circ}$, 36, 52, 92, 93, 95, 98, 99, 102, 103, 104, 105, 107, 109, 111, 112, 114, 115, 125, 126, 127, 128, 129 , 134 e 168 da Constituição Federal, e acrescenta os arts. 103-A, 103B, 111-A e 130-A, e dá outras providências. Disponível em: <http://goo.gl/JHetdb>. Acesso em: 19 jul. 2015.

. Decreto $\mathrm{n}^{0}$ 7.030, de 14 de dezembro de 2009. Promulga a Convenção de Viena sobre o Direito dos Tratados, concluída em 23 de maio de 1969, com reserva aos Artigos 25 e 66. Disponível em: <http://goo.gl/wQ3MWl>. Acesso em: 19 jul. 2015.

. Supremo Tribunal Federal. Acórdão. Recurso Extraordinário 466.343-1, Relator Min. Cezar Peluzo, Voto-vogal do Min. Gilmar Mendes.

Supremo Tribunal Federal. Acórdão. ADI-MC 1.480. Relator: Min. Celso de Mello. Brasília, 04/09/1997. Publicado em 18/05/2001.

. Supremo Tribunal Federal. Recurso Extraordinário 466.343-1, Relator Min. Cezar Peluzo, Voto-vogal do Min. Gilmar Mendes.

BOBBIO, Norberto. Positivismo Jurídico: Lições sobre a filosofia do Direito. Trad. Marcio Publiesi, Edson Bini, Carlos E. Rodrigues. São Paulo: Ícone, 1995.

- Teoria do Ordenamento Jurídico. Trad. Maria Celeste. Brasília: Editora Universidade de Brasília, 6. ed., 1995.

CAPPELLETTI, Mauro; GARTH, Bryant. Acesso à Justiça. Tradução de Ellen Gracie Northfleet. Porto Alegre: Sérgio Antonio Fabris, 1988.

. Juízes Legisladores? Tradução de Carlos Alberto Álvaro de Oliveira. Porto Alegre: Sérgio Antonio Fabris, 1999.

KELSEN, Hans. Teoria Pura do Direito. 6. ed. São Paulo: Martins Fontes, 1998. Jurisdição constitucional. São Paulo: Martins Fontes, 2007.

MARINONI, Luiz Guilherme; MAZZUOLI, Valério de Oliveira. Controle de Convencionalidade. São Paulo: Gazeta Jurídica, 2013.

MAZZUOLI, Valério de Oliveira. O Controle Jurisdicional da Convencionalidade das leis. 3. ed. São Paulo: Revista dos Tribunais, 2013.

MEINECKE, F. Machiavelism: The Doctrine of Raison d'Etat and its Place in Modern History. London: Routledge and Kegan Paul, 1957.

NALINI, José Renato (Org). Magistratura e ética: perspectivas. São Paulo: Contexto, 2013. 
ORGANIZAÇÃO DOS ESTADOS AMERICANOS. Convenção Americana de Direitos Humanos (1969). Disponível em: <http://goo.gl/Unrz04>. Acesso em: 20 jul. 2015.

- Corte Interamericana de Direitos Humanos. Casos dos trabalhadores demitidos do Congresso vs. Peru. Voto fundamentado do juiz Sergio García Ramirez, de 24.11.2006. Disponível em: <http://goo.gl/4tbGnV>. Acesso em: 10 jul. 2015.

RAMOS, André de Carvalho. Supremo Tribunal Federal Brasileiro e o Controle de Convencionalidade: Levando a sério os tratados de direitos humanos. Revista da Faculdade de Direito da Universidade de São Paulo. V 104. p. 241-286. jan/dez.2009.

RUSSOWSKY, Iris Saraiva. O Controle de Convencionalidade das leis: uma análise na esfera internacional e interna. Revista do CAAP. Belo Horizonte. N 2. v. XVIII. p. 61-96, 2012.

SCHMITT, Carl. La Defensa de la Constitución. Madrid: Tecnos, 1998.

. O guardião da Constituição. Belo Horizonte: Del Rey, 2007.

TRIBUNAL EUROPEU DOS DIREITOS DO HOMEM. Convenção Europeia dos Direitos do Homem. Disponível em: <http://goo.gl/JxqYpq>. Acesso em: 20 jun. 2015.

TRINDADE, Antônio Augusto Cançado. A proteção internacional dos direitos humanos e o Brasil (1948-1997): as primeiras cinco décadas. 2. ed. Brasília: Editora Universidade de Brasília, 2000.

. A proteção internacional dos direitos humanos no limiar do novo século e as perspectivas brasileiras. Temas de política externa brasileira II. Brasília: Ministério das Relações Exteriores, 1994, v. 1.

. Os Tribunais Internacionais Contemporâneos. Brasília: FUNAG, 2013.

- Tratado de Direito Internacional dos Direitos Humanos; vol. 3; Porto Alegre: Editora Sérgio Antonio Fabris, 2003.

. Tratado Internacional de Direito Humanos. Porto Alegre: Sérgio Fabris, 2010.

\title{
THE CONVENTIONALITY CONTROL AND THE SELF-ASSESSMENT OF BRAZILIAN JUDICIARY
}

\begin{abstract}
The phenomenon known as conventionality control of laws changed the way of understanding the Law in the contemporary world, putting together subjects of international law and domestic law methodologies. However, many questionings regarding this regulatory control still persist. The purpose of this paper is to discuss how the conventionality control has transformed the Judicial Branch's understanding about the implementation of human rights in Brazil. Using an analyticalcritical methodology, it is observed that the conventionality control, more than a normative control exercise, is an opportunity for the Judiciary to review its concepts about itself.
\end{abstract}




\section{KEYWORDS}

Conventionality control. Inter-American System for the Protection of Human Rights. Judicial Branch.

Recebido: 3 de novembro de 2015

Aprovado: 14 de dezembro de 2015 